\title{
Evaluation of Immune Biomarkers After Oral Administration of Biofield Energy Healing Based Herbomineral Formulation in Male Sprague Dawley Rats
}

\author{
Mahendra Kumar Trivedi ${ }^{1}$, Alice Branton ${ }^{1}$, Dahryn Trivedi ${ }^{1}$, Gopal Nayak ${ }^{1}$, \\ Cathryn Dawn Nykvist ${ }^{1}$, Celine Lavelle ${ }^{1}$, Daniel Paul Przybylski ${ }^{1}$, Dianne Heather Vincent ${ }^{1}$, \\ Dorothy Felger ${ }^{1}$, Douglas Jay Konersman ${ }^{1}$, Elizabeth Ann Feeney ${ }^{1}$, Jay Anthony Prague ${ }^{1}$, \\ Joanne Lydia Starodub ${ }^{1}$, Karan Rasdan ${ }^{1}$, Karen Mie Strassman ${ }^{1}$, Leonid Soboleff ${ }^{1}$, \\ Maire Anne Mayne ${ }^{1}$, Mary M. Keesee ${ }^{1}$, Padmanabha Narayana Pillai ${ }^{1}$, Pamela Clarkson Ansley ${ }^{1}$, \\ Ronald David Schmitz ${ }^{1}$, Sharyn Marie Sodomora ${ }^{1}$, Sambhu Charan Mondal' ${ }^{2}$, Snehasis Jana ${ }^{2,}$, \\ ${ }^{1}$ Trivedi Global, Inc., Henderson, Nevada, USA \\ ${ }^{2}$ Trivedi Science Research Laboratory Pvt. Ltd., Bhopal, Madhya Pradesh, India
}

Email address:

publication@trivedieffect.com (S. Jana)

*Corresponding author

\section{To cite this article:}

Mahendra Kumar Trivedi, Alice Branton, Dahryn Trivedi, Gopal Nayak, Cathryn Dawn Nykvist, Celine Lavelle, Daniel Paul Przybylski, Dianne Heather Vincent, Dorothy Felger, Douglas Jay Konersman, Elizabeth Ann Feeney, Jay Anthony Prague, Joanne Lydia Starodub, Karan Rasdan, Karen Mie Strassman, Leonid Soboleff, Maire Anne Mayne, Mary M. Keesee, Padmanabha Narayana Pillai, Pamela Clarkson Ansley, Ronald David Schmitz, Sharyn Marie Sodomora, Sambhu Charan Mondal, Snehasis Jana. Evaluation of Immune Biomarkers after Oral Administration of Biofield Energy Healing Based Herbomineral Formulation in Male Sprague Dawley Rats. International Journal of Biochemistry, Biophysics \& Molecular Biology. Vol. 2, No. 6, 2017, pp. 80-88. doi: 10.11648/j.ijbbmb.20170206.15

Received: October 30, 2017; Accepted: November 10, 2017; Published: December 11, 2017

\begin{abstract}
The natural products based formulations usage have been increased world-wide in health care sector due to their high safety and better therapeutic action. A new proprietary herbomineral formulation was formulated with four ingredients; a mixture of the minerals (zinc, magnesium, and selenium) and the herbal root extract ashwagandha. The aim of the study was to evaluate the immunomodulatory potential of Biofield Energy Healing (The Trivedi Effect ${ }^{\mathbb{B}}$ ) on the herbomineral formulation in male Sprague Dawley (SD) rats. The test formulation was divided into two parts. One part was denoted as the control without any Biofield Energy Treatment, while the other part was defined as the Biofield Energy Treated sample, which received the Energy of Consciousness Healing Treatment remotely from eighteen renowned Biofield Energy Healers. The immunomodulatory effect of the Biofield Energy Treated and untreated test formulations was studied in SD rats to determine any alteration in humoral immune response (IgG and $\operatorname{IgM})$, cellular immune response, hematological parameters, lipid profile, hepatic enzymes, and the sex hormone (testosterone). The ratio of $\mathrm{CD}^{+} / \mathrm{CD}^{+}$was significantly increased by $51.98 \%$ and $12.99 \%(p \leq 0.05)$ in the Biofield Energy Treated (G3) and untreated test formulations (G4), respectively compared with the disease control group (G2). The level of IgM was significantly increased by $28.57 \%$ in the G3 group, while decreased by $14.29 \%$ in the G4 group compared with the G2 group. The eosinophil count was significantly increased by $27.27 \%$ in the G3 group, while decreased by $18.18 \%$ in the G4 group compared with the G2 group. The levels of triglycerides (TG) and very low density lipoproteins (VLDL) were reduced by $8.99 \%$ and $9.12 \%$, respectively in the G3 group compared with the G2 group. However, the levels of TG and VLDL were reduced by $2.40 \%$ and $3.46 \%$, respectively in the G4 group compared with the G2 group. Among the tested hepatic parameters, results showed decreased levels of serum glutamate oxaloacetate transaminase (SGOT) and creatine kinase myocardium band (CK-MB) by $42.65 \%(p<0.01)$ and $7.67 \%$, respectively in the Biofield Energy Treated test formulation group (G3) compared to the G2 group. The level of testosterone was significantly increased by $22.02 \%$ in the G3 group compared with G2 group. The overall results demonstrated that the Biofield Energy Treated test formulation showed better immune response compared with the untreated test formulation. These data suggest that the Biofield Energy Treated test formulation can be used for autoimmune and inflammatory diseases, stress management and anti-aging by
\end{abstract}


improving overall health.

Keywords: Biofield Energy Healing Treatment, Biofield Energy Healers, The Trivedi Effect ${ }^{\circledR}$, Herbomineral Formulation, Immune-modulation, Testosterone, Anti-aging, Inflammatory Disease and Stress Management

\section{Introduction}

In developing and developed countries alike, medicinal plant-derived drugs are continuously gaining popularity due to their natural origin, high safety, better therapeutic response, and less side effects. Many traditional and complementary medicines are derived from medicinal plants, minerals, and organic matter, which are commonly used for the prevention and treatment of many diseases. The therapeutic properties of the plant extracts have been recognized and utilized worldwide since ancient times $[1,2]$. Scientific studies have identified the immunomodulatory properties of medicinal plants, which can be further potentiated with the addition of some minerals that regulate the immune cells. These types of formulations are welldefined as herbomineral formulations and are the major target of pharmaceutical companies as daily dietary supplements. However, the use of natural remedies has gained importance when the conventional medicines are ineffective for certain diseases. Herbal and traditional medicines are suitable candidates for the new therapeutics due to their vast chemical diversity and various biological effects [2]. Several marketed medicinal formulations are in use, but the serious concern is the safety issues, as most of them are associated with the side effects [4]. With respect to the safety issues, a new proprietary herbomineral formulation was formulated with a combination of the herb Withania somnifera (ashwagandha) root extract and three minerals viz. zinc, magnesium, and selenium. All the individual components have been reported with significant biological activities such as antioxidant, anti-inflammatory, anti-viral, and immune modulating [5-7]. In general, the ashwagandha plant has been reported for immunomodulatory activity, antitumor, antibacterial effects, a role in cancer treatment, and many more with available pre-clinical and clinical reports $[8,9]$. Besides, the minerals such as selenium, zinc, copper, and magnesium have been reported for a beneficial role in immunomodulation [5].

In recent years, several scientific reports along with clinical trials have shown the useful effects of Biofield Energy Therapy worldwide as an alternative treatment method, which has been known for its significant impact on cancerous cells [10]. With respect to many scientific reports, the Energy of Consciousness Healings Treatment (Biofield Energy Healing) have been reported to have significant outcomes that may prove to be a more cost effective alternative than other approaches [11]. The use of Complementary and Alternative Medicine (CAM) therapies have increased as the preferred mode of treatment, among which Biofield Therapy (or Healing Modalities) is one approach that has been reported to have several benefits to enhance physical, mental, and emotional human wellness. However, the Biofield Energy can exist in different forms such as kinetic, magnetic, potential, electrical, and electromagnetic. The human body has the power to produce low intensity electromagnetic signals known as the Biofield. Thus, a human has the ability to harness energy from the environment and transmit it to any living or nonliving object(s) around the globe. The objects always receive the energy and respond in a useful way. This process is known as Biofield Energy Healing Treatment (The Trivedi Effect ${ }^{\circledR}$ ). Based on the literature data, the Biofield Energy Treatment in terms of a Complementary and Alternative Medicine (CAM) approach was practiced worldwide [12]. The National Center of Complementary and Integrative Health (NCCIH) has recognized and accepted Biofield Energy Healing as a Complementary and Alternative Medicine (CAM) health care approach in addition to other therapies, medicines and practices such as natural products, deep breathing, yoga, Tai Chi, Qi Gong, chiropractic/osteopathic manipulation, meditation, massage, special diets, homeopathy, progressive relaxation, guided imagery, acupressure, acupuncture, relaxation techniques, hypnotherapy, healing touch, movement therapy, pilates, rolfing structural integration, mindfulness, Ayurvedic medicine, traditional Chinese herbs and medicines, naturopathy, essential oils, aromatherapy, Reiki, and cranial sacral therapy. To this day, Biofield Energy Healing has had a significant impact in the transformation of living organisms and nonliving materials including metals, polymers, ceramics, chemicals, and pharmaceutical compounds. In addition, Biofield Energy Healing Treatment (The Trivedi Effect ${ }^{\circledR}$ ) outcomes have been published in numerous peer-reviewed science journals due to its significant impact in many scientific fields such as cancer research [13, 14], microbiology [15-18], genetics [19, 20], pharmaceutical science [21-24], agricultural science [2528], and in materials science [29-32]. In this study, the authors evaluated the impact of the Energy of Consciousness Healing (The Trivedi Effect ${ }^{\mathbb{B}}$ ) Treatment on the designated herbomineral formulation for immunomodulatory potential with respect to the cellular and humoral immune response, hematological parameters, lipid profile, hepatic enzymes, and sex hormone in male Sprague Dawley rats.

\section{Materials and Methods}

\subsection{Chemicals and Reagents}

Ashwagandha root extract powder was procured from Sanat Products Ltd., India. Zinc chloride and magnesium (II) 
gluconate hydrate were procured from TCI, Japan. Sodium selenate was procured from Alfa Aesar, USA. Pyrogallol, Levamisole hydrochloride, and sodium carboxymethyl cellulose (Na-CMC) were procured from Sigma Chemical Co. (St. Louis, MO). All the other chemicals used in this experiment were analytical grade procured from India.

\subsection{Laboratory Animals}

Randomly breed Sprague Dawley (SD) male rats were purchased from M/s. Vivo Bio Tech Ltd., Hyderabad, India. The animals were divided into six groups $(n=6)$ based on their body weight. Illumination was controlled to give 12 hours light and 12 hours dark cycle during the 24 hours period alongwith a temperature of $22 \pm 3^{\circ} \mathrm{C}$, humidity of $30 \%$ to $70 \%$. Standard chow diet was procured from $\mathrm{M} / \mathrm{s}$. Golden feeds, Mehrauli, New Delhi, India was provided ad libitum to all the groups of animals during the experiment. The animals were received reverse osmosis filtered drinking water ad libitum by a water dispensing bottle. All the procedures were in strict accordance with the Guide for the Care and Use of Laboratory Animals published by the US National Institutes of Health. The approval of animal experiment was obtained by the Institutional Animal Ethics Committee prior to conduct an experiment.

\subsection{The Trivedi Effect ${ }^{\circledR}$ - Energy of Consciousness Treatment Strategies}

The herbomineral test formulation was divided into two parts. One part of the test formulation was treated with Biofield Energy by renowned Consciousness Energy Healers (also known as The Trivedi Effect ${ }^{\circledR}$ ) and coded as the Biofield Energy Treated formulation, while the second part of the test formulation did not receive any sort of treatment and was defined as the untreated test formulation. This Biofield Energy Treatment was provided to the test formulation through a group of eighteen Biofield Energy Healers who participated in this study and performed the Biofield Energy Treatment remotely. Eleven Biofield Energy Healers were remotely located in the U.S.A., four were remotely located in Canada, one in the UK, one in Russia and one in Ireland. The test herbomineral formulation was located in the research laboratory of Dabur Research Foundation, New Delhi, India. This Biofield Treatment was administered for 5 minutes through the Healer's Unique Energy Transmission process remotely to the test formulation under the laboratory conditions. Besides, one group of animals was also received Biofield Energy Treatment by the same Biofield Energy Healers under similar conditions. None of the Biofield Energy Healers in this study visited the laboratory in person, nor had any contact with the herbomineral samples. Further, the control group was treated with a "sham" healer for comparative purpose. The sham healer did not have any knowledge about the Biofield Energy Treatment. After that, the Biofield Energy Treated and untreated test formulation were returned in the similar sealed condition and kept in recommended storage condition.

\subsection{Antigen (Sheep RBC)}

The blood was obtained from the jugular vein of a healthy sheep and transferred immediately to the heparinized tube. Then erythrocytes were separated from plasma by centrifugation $\left(400 \mathrm{~g}, 10^{\circ} \mathrm{C}, 10\right.$ minutes $)$, washed twice with the normal saline and then further diluted in the saline and the samples were analyzed by Hematology analyzer (Abbott Model-CD-3700). Depending on the number of erythrocytes in the the samples were further diluted (using saline) before injecting to the rat [33].

\subsection{Experimental Procedure}

After 5 days of acclimatization, the animals were randomized and grouped based on the body weight. Normal control (G1) was received an oral suspension of $0.5 \%$ carboxy methyl cellulose-sodium salt via gavage. The disease control group (G2) was received pyrogallol through intraperitoneal (i.p.) route at a dose of $100 \mathrm{mg} / \mathrm{kg}$ once daily for 7 days. The G3 and G4 animals were received the Biofield Energy Treated and untreated test formulations, respectively at $1105.005 \mathrm{mg} / \mathrm{kg} \mathrm{b}$.wt, p.o. The G5 animals received levamisole at a dose of $50 \mathrm{mg} / \mathrm{kg}$ p.o. The G6 animals were received the Biofield Energy Treatment per se at day -15 . Further, all the animals except normal control group (G1) received pyrogallol at a dose of $100 \mathrm{mg} / \mathrm{kg}$ through i.p. route once daily from day 1 to day 7 . The animals were treated with the Biofield Energy Treated and untreated herbomineral formulations to the G3 and G4 animals respectively, 1 hour before pyrogallol challenge in the morning once daily for 22 days. On day $7^{\text {th }}$ and $13^{\text {th }}$, all the animals in the $\mathrm{G} 2$ to G6 except G1 were challenged with sheep red blood cells (sRBC) $\left(0.5 \times 10^{9} / 100 \mathrm{gm}\right.$; i.p.), as the antigenic material to sensitize them for immunological parameters. The animals were kept on overnight fasting on day 22. The next day on day 23 the animals were bled and the samples were subjected for humoral immune response (IgG and $\operatorname{IgM}$ ), cellular immune response $\left(\mathrm{CD}^{+}\right.$and $\left.\mathrm{CD} 8^{+}\right)$, hematology, biochemistry, and sex hormone (testosterone). After bleeding all the animals were euthanized using $\mathrm{CO}_{2}$ asphyxiation followed by exsanguination.

\subsection{Assessment of Cellular and Humoral Immune Responses}

For humoral immune response, the immunoglobulins such as $\mathrm{IgG}$ and $\mathrm{IgM}$ were estimated using Mini Vidas, Biomeurix (French) from serum, using commercially available kits. Flow cytometry was used to evaluate the $\mathrm{CD} 4^{+}$and $\mathrm{CD} 8^{+}$ cells in blood as a measure of the cellular immune response. The mean value was calculated for each group with SEM. The percent change in treated group were calculated as compared to vehicle treatment group.

\subsection{Measurement of Hematology Parameters}

On $23^{\text {rd }}$ day of the experiment, blood was collected from 
the retro-orbital plexus using capillary tubes and hematology parameters such as total leukocyte count (TLC) and five parts differential leukocyte count (DLC) were analysed using Hematology analyzer (Abbott Model-CD-3700).

\subsection{Measurement of Lipid Profile and Hepatic Enzymes}

Serum biochemistry parameters such as total cholesterol (TC), triglycerides (TG), low density lipoprotein (LDL), high density lipoprotein (HDL), very low density lipoprotein (VLDL), alkaline phosphatase (ALP), serum glutamic oxaloacetic transaminase (SGOT), and serum glutamatepyruvate transaminase (SGPT) were analysed in the test formulation.

\subsection{Measurement of Sex Hormone}

Testosterone was analysed in serum using commercial kits. The mean value was calculated for each group with SEM.

\subsection{Statistical Analysis}

The data were expressed as mean \pm standard error of mean (SEM) and subjected to statistical analysis using Sigma Plot (Version 11.0). Student's $t$-test was done with a comparison among control and treatment groups. The $p \leq 0.05$ was considered as statistically significant.

\section{Results and Discussion}

\subsection{Measurement of Cellular Responses}

The effects of the Biofield Energy Treated and untreated test formulation on the ratio of $\mathrm{CD} 4^{+} / \mathrm{CD} 8^{+}$in male rats are shown in the Figure 1 . The ratio of $\mathrm{CD}^{+} / \mathrm{CD}^{+}$was 1.40 , $3.54,5.38,4.00,7.19$, and 3.51 in the normal control (G1), disease control (G2), Biofield Energy Treated test formulation (G3), untreated test formulation (G4), levamisole (G5), and Biofield Energy Treatment group per se at day -15 (G6), respectively. Results suggest that the ratio was increased by $51.98 \%, 12.99 \%$, and $103.11 \%$ $(p \leq 0.05)$ in the $\mathrm{G} 3, \mathrm{G} 4$, and $\mathrm{G} 5$ groups, respectively compared with the $\mathrm{G} 2$ group. It was reported that the $\mathrm{CD} 4^{+}$ cells can protect and fight against infections, while $\mathrm{CD} 8^{+}$ cells can have the capacity to kill cancer cells and other invaders. The ratio of $\mathrm{CD}^{+} / \mathrm{CD}^{+}$reflect the health of the immune system and the normal ratio is suggested as 2 . If the ratio is higher, it suggest that the immune system is stronger as compared with the low ratio of $\mathrm{CD}^{+} / \mathrm{CD} 8^{+}$, which reflects infection $[34,35]$. The experimental results suggest that the Biofield Energy Treated test formulation improved the ratio of $\mathrm{CD}^{+} / \mathrm{CD}^{+}$by $51.98 \%$, while the untreated test formulation increased by $12.99 \%$. This suggest that The Trivedi Effect ${ }^{\circledR}$ has the capacity to do significant change in the immune system, and the Biofield Energy Treated test formulation has the capacity to modulate the overall immune function.

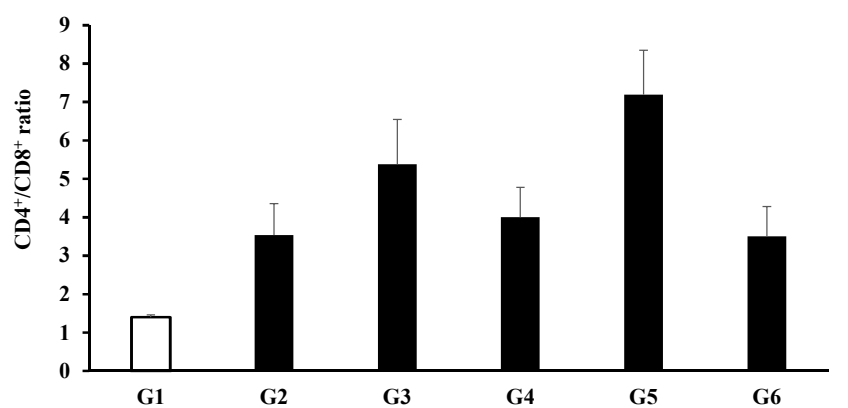

Figure 1. The effects of the Biofield Energy Treated and untreated test formulations on cellular immune-biomarkers $\left(C D 4^{+}\right.$and $\left.C D 8^{+}\right)$after 22 consecutive days of treatment in male rats by oral route. G: Group; G1: Normal control; G2: Disease control; G3: Biofield Energy Treated test formulation; G4: Untreated test formulation; G5: Levamisole; G6: Biofield Energy Treatment group per se at day -15. All the values are represented as mean $\pm \operatorname{SEM}(n=6) ; * p \leq 0.05$ vs $G 2$.

\subsection{Measurement of Humoral Responses}

Antibody molecules, a product of B lymphocytes and plasma cells, are the central component to produce humoral immune responses. The IgG and IgM are the major immunoglobulin which are involved in the complement activation, opsonization, neutralization of toxins, etc. The effects of both the Biofield Energy Treated and untreated test formulations of IgM and IgG levels in male rats are shown in the Figures 2 and 3, respectively. The levels of IgM and IgG were increased by $40 \%$ and $19.5 \%$, respectively in the disease control group (G2) compared with the normal control (G1). Further, IgM was increased by $28.57 \%$ in the Biofield Energy Treated group (G3), while decreased by $14.29 \%$ in the untreated test formulation compared with the $\mathrm{G} 2$ group. Besides, the level of $\mathrm{IgG}$ was reduced by $19.67 \%$ and $11.72 \%$ in the Biofield Energy Treated and untreated formulation groups, respectively compared with the G2 group. The Biofield Energy Treatment group per se (day -15) (G6) showed $16 \%$ reduction of IgG level compared with the G2 group. Additionally, the levels of IgM and IgG were reduced by $28.57 \%$ and $13.39 \%$, respectively in the positive control (levamisole) group (G5) compared with the G2. Yamada et al. had reported that ashwagandha enhance the immune function by increasing immunoglobulin production [36]. Experimental studies reported that an influence of zinc nutriture on the balance between lymphocyte TH1 elements and functions (cell-mediated immunity) and $\mathrm{TH} 2$ elements and functions (humoral immunity). Deficiency of zinc induces the production of a low-molecular-weight humoral factor [37]. In this experiment, the Biofield Energy Treated test formulation showed significant an increased in the level of IgM compared to the both untreated test formulation and disease control groups. The data was support with the findings of Yamada and Solomons et al. [36, 37]. 


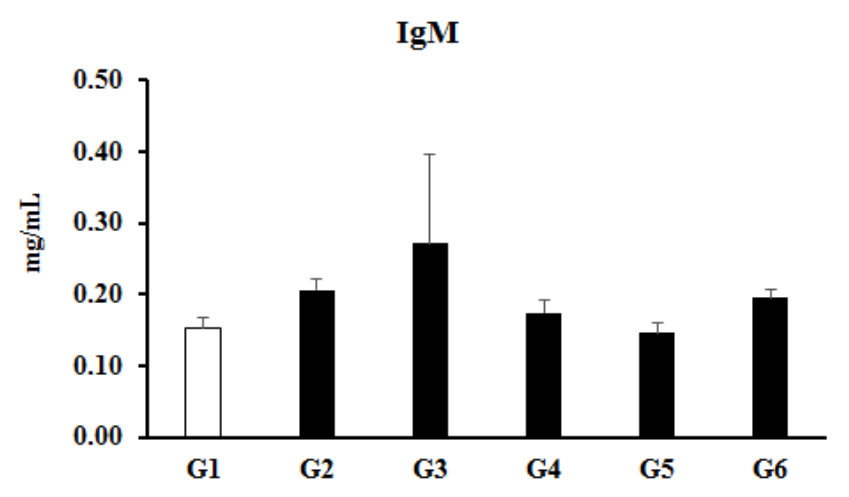

Figure 2. The effects of the Biofield Energy Treated and untreated test formulations on immunoglobulin $(\operatorname{IgM})$. All the values are represented as mean $\pm \operatorname{SEM}(n=6)$.

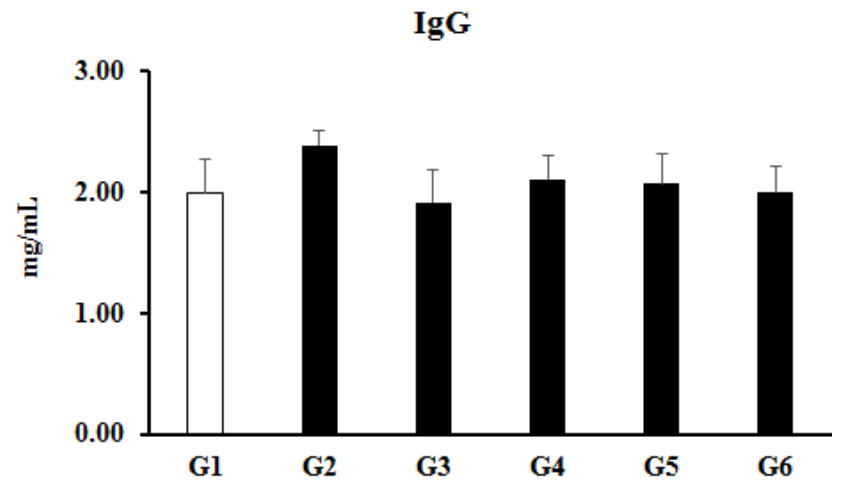

Figure 3. The effects of the Biofield Energy Treated and untreated test formulations on immunoglobulin $(\operatorname{IgG})$. All the values are represented as mean $\pm \operatorname{SEM}(n=6)$.

\subsection{Measurement of Hematology Parameters}

The results of the hematology parameters such as total and differential leucocytes counts are shown in the Table 1 .
Immunosuppression induced by pyrogallol showed a reduction of TLC, neutrophils, and monocytes by $2.56 \%$, $17.26 \%$, and $16.5 \%$, respectively in the disease control group (G2) compared with the normal control group (G1). The TLC was increased by $2.39 \%$ and $16.71 \%$ in the Biofield Energy Treated test formulation (G3) and untreated test formulation group (G4), respectively compared with the G2. The eosinophil level was increased by $27.27 \%$ in the G3 group, while decreased by $18.18 \%$ in the G4 group compared with the G2. The levels of TLC, neutrophils, and monocytes were increased by $11.58 \%, 8.91 \%$, and $19.76 \%$, respectively in the Biofield Energy Treatment group per se (day -15) (G6) compared with the G2 group. However, the levels of lymphocytes and eosinophils were decreased by $1.68 \%$ and $27.32 \%$, respectively in the Biofield Energy Treatment group per se (day -15) (G6) compared with the G2 group. The positive control levamisole showed $12.41 \%, 21.09 \%$, and $19.76 \%$ increased in the levels of TLC, neutrophils, and monocyte, respectively compared with the G2.

The eosinophils play the role of a beneficial modulatory element or an innocent bystander. Jung et al. (2014) an increasing number of experimental observations indicate that eosinophils has multifunctional leukocytes involved in diverse inflammatory and physiologic immune responses. They have found that the potential role of eosinophils as a modulators of the intestinal immune system [38]. This study therefore demonstrated that the Biofield Energy Treated test formulation showed significant an increased the level of eosinophil by $35.62 \%$ compared with the untreated test formulation. Another researcher has reported that the effects of eosinophils and neutrophils in the protective innate immune response. Besides, the Biofield Energy Treated group also increased the level of neutrophil by $8.91 \%$ compared with the disease control. The data were well supported with literature [39].

Table 1. Effects of the Biofield Energy Treated and untreated test formulations on hematological parameters.

\begin{tabular}{|c|c|c|c|c|c|}
\hline Group & TLC $\left(10^{3} / \mathrm{mm}^{3}\right)$ & Neutrophils (\%) & Lymphocytes (\%) & Eosinophils (\%) & Monocyte (\%) \\
\hline G1 & $8.60 \pm 0.64$ & $20.33 \pm 1.23$ & $75.83 \pm 1.51$ & $1.83 \pm 0.40$ & $2.00 \pm 0.52$ \\
\hline $\mathrm{G} 2$ & $8.38 \pm 0.72$ & $16.83 \pm 2.34$ & $79.67 \pm 1.98$ & $1.83 \pm 0.40$ & $1.67 \pm 0.21$ \\
\hline G3 & $8.58 \pm 1.33$ & $17.33 \pm 1.93$ & $79.17 \pm 2.01$ & $2.33 \pm 0.42$ & $1.17 \pm 0.17$ \\
\hline G4 & $9.78 \pm 1.19$ & $17.33 \pm 2.56$ & $79.50 \pm 2.50$ & $1.50 \pm 0.34$ & $1.67 \pm 0.21$ \\
\hline G5 & $9.42 \pm 0.92$ & $20.83 \pm 2.87$ & $75.83 \pm 3.04$ & $1.33 \pm 0.21$ & $2.00 \pm 0.00$ \\
\hline G6 & $9.35 \pm 1.09$ & $18.33 \pm 1.48$ & $78.33 \pm 1.50$ & $1.33 \pm 0.21$ & $2.00 \pm 0.00$ \\
\hline
\end{tabular}

Analysis of the hematological profile like total and differential ( 5 parts) counts of white blood corpuscles after consecutive 22 days treatment of the test formulation in male rats. All the values are represented as mean \pm SEM $(n=6)$. TLC: Total leukocyte count; \%: Percentage

\subsection{Measurement of Lipid Biomarkers}

The effects of the Biofield Energy Treated and untreated test formulations on the serum lipid profile are presented in the Table 2. Immunosuppression was induced by pyrogallol showed reduction of all the lipid parameters such as total cholesterol, TG, HDL, LDL, and VLDL by $8.18 \%, 21.78 \%$,
$7.71 \%, 4.60 \%$, and $21.86 \%$, respectively in the disease control group (G2) compared with the normal control group (G1). The levels of total cholesterol, TG, LDL, and VLDL were reduced by $1.3 \%, 8.99 \%, 0.23 \%$, and $9.12 \%$, respectively in the Biofield Energy Treated group (G3) compared with the G2. Besides, the untreated test formulation group (G4) exhibited the decrease levels of TG and VLDL by $2.40 \%$ and $3.46 \%$, respectively compared with the G2. There was a significant reduction by $31.64 \%$ and $31.81 \%(p \leq 0.05)$ of the levels of TG and VLDL, respectively in the Biofield Energy Treatment group per se (day -15) (G6) compared with the $\mathrm{G} 2$ group. 
Table 2. Effects of the Biofield Energy Treated and untreated test formulations on the lipid biomarkers in serum sample.

\begin{tabular}{llllll}
\hline Group & Total Cholesterol (mg/dL) & Triglyceride (mg/dL) & HDL (mg/dL) & LDL (mg/dL) & VLDL (mg/dL) \\
\hline G1 & $73.13 \pm 4.90$ & $61.85 \pm 3.96$ & $15.82 \pm 0.96$ & $44.97 \pm 5.19$ & $12.35 \pm 0.79$ \\
G2 & $67.15 \pm 5.89$ & $48.38 \pm 3.61$ & $14.60 \pm 0.85$ & $42.90 \pm 5.34$ & $9.65 \pm 0.72$ \\
G3 & $66.28 \pm 5.14$ & $44.03 \pm 3.86$ & $14.72 \pm 1.36$ & $42.80 \pm 4.86$ & $8.77 \pm 0.78$ \\
G4 & $69.50 \pm 2.56$ & $47.22 \pm 3.65$ & $17.42 \pm 1.16$ & $42.67 \pm 2.88$ & $9.42 \pm 0.73$ \\
G5 & $81.20 \pm 2.16$ & $49.78 \pm 2.99$ & $15.60 \pm 1.09$ & $55.67 \pm 2.25$ & $9.93 \pm 0.60$ \\
G6 & $69.87 \pm 2.12$ & $33.08 \pm 4.95$ & $14.28 \pm 0.94$ & $49.00 \pm 2.81$ & $6.58 \pm 0.99^{*}$ \\
\hline
\end{tabular}

Assessment of lipid profiles after 22 days of treatment of the test formulation in male rats. The values are represented as Mean \pm SEM $(\mathrm{n}=6) .{ }^{*} p \leq 0.05$ (as compared to the disease control); HDL: High density lipoprotein; LDL: Low density lipoprotein; VLDL: Very low density lipoprotein; mg/dL: Milligram per deciliter

\subsection{Measurement of Hepatic and Cardiac Biomarkers}

The effect of the test formulation on the hepatic and cardiac parameters is depicted in the Table 3 . The pyrogallol induced disease control group (G2) showed significant $(p \leq 0.05)$ increased the hepatic enzymes such as SGOT and SGPT by $5.73 \%$ and $64.34 \%$, respectively compared with the normal control group (G1). The levels of SGOT, CK-MB, and $\mathrm{A} / \mathrm{G}$ ratio were reduced by $2.20 \%, 7.67 \%$, and $1.20 \%$, respectively in the Biofield Energy Treated group (G3) compared with the G2. Additionally, the level of SGOT was significantly $(p \leq 0.05)$ reduced in the Biofield Energy Treatment group per se (G6) by $42.65 \%$ compared with the G2. Others parameters like total bilirubin, ALP, total protein, $A$, and $\mathrm{G}$ did not show any significant alteration compared with the disease control group. In this experiment, the Biofield Energy Treatment group per se (G6) significantly decreased the level of SGOT compared with the G2 group, which could be beneficial in most of the immunodeficiency patients. It is assumed that the reduction of SGOT value might be due to the effect of the constituents present in the herbomineral test formulation like ashwagandha and others minerals. Based on the literature it was reported that ashwagandha reduced the level of SGOT level in rats. The data were corroborated with the current findings [40].

Table 3. Effects of the Biofield Energy Treated and untreated test formulations on the hepatic and cardiac biomarkers in male rats.

\begin{tabular}{llllllllll}
\hline Group & SGOT (U/L) & SGPT (U/L) & ALP (U/L) & CK-MB (U/L) & $\begin{array}{l}\text { Tot. BL } \\
(\mathbf{m g} / \mathbf{d L})\end{array}$ & $\begin{array}{l}\text { Tot. Prot. } \\
(\mathbf{g} / \mathbf{d L})\end{array}$ & A (g/dL) & G (g/dL) & A/G ratio \\
\hline G1 & $334.0 \pm 18.42$ & $36.57 \pm 1.75$ & $293.3 \pm 14.96$ & $1265.30 \pm 109.14$ & $0.13 \pm 0.01$ & $5.45 \pm 0.13$ & $3.40 \pm 0.03$ & $2.05 \pm 0.11$ & $1.65 \pm 0.11$ \\
G2 & $353.1 \pm 33.59^{\#}$ & $60.10^{\#} \pm 16.58$ & $258.2 \pm 14.35$ & $1206.63 \pm 240.22$ & $0.09 \pm 0.01$ & $5.38 \pm 0.04$ & $3.38 \pm 0.03$ & $2.00 \pm 0.06$ & $1.67 \pm 0.06$ \\
G3 & $345.38 \pm 12.32$ & $86.43 \pm 20.81$ & $273.4 \pm 13.82$ & $1114.08 \pm 111.71$ & $0.12 \pm 0.01$ & $5.57 \pm 0.10$ & $3.48 \pm 0.05$ & $2.08 \pm 0.11$ & $1.65 \pm 0.09$ \\
G4 & $433.00 \pm 41.32$ & $78.43 \pm 22.40$ & $288.2 \pm 15.22$ & $1448.57 \pm 266.95$ & $0.14 \pm 0.01$ & $5.68 \pm 0.17$ & $3.45 \pm 0.06$ & $2.23 \pm 0.11$ & $1.52 \pm 0.06$ \\
G5 & $256.02 \pm 31.60$ & $44.92 \pm 3.64$ & $263.1 \pm 23.04$ & $731.70 \pm 126.21$ & $0.11 \pm 0.01$ & $5.57 \pm 0.03$ & $3.37 \pm 0.02$ & $2.30 \pm 0.09$ & $1.43 \pm 0.06$ \\
G6 & $202.5 \pm 15.89^{\circledR}$ & $50.32 \pm 5.37$ & $320.2 \pm 13.33$ & $406.57 \pm 82.25$ & $0.11 \pm 0.01$ & $5.53 \pm 0.16$ & $3.42 \pm 0.03$ & $2.12 \pm 0.13$ & $1.62 \pm 0.10$ \\
\hline
\end{tabular}

Assessment of the hepatic and cardiac biomarkers of the Biofield Energy Treated and untreated test formulation in male rats. The values are represented as mean \pm SEM $(n=6)$. ${ }^{\#} p \leq 0.05$ (as compared to the normal control); ${ }^{\circledR} p \leq 0.05$ (as compared to the disease control); SGOT: Serum glutamic oxaloacetic transaminase; SGPT: Serum glutamate-pyruvate transaminase; ALP: Alkaline phosphatase; CK-MB: Creatine kinase-myocardial band; Tot. BL: Total bilirubin; Tot. Prot.: Total protein; A: Albumin; G: Globulin; A/G: Albumin/Globulin ratio; U/L: Unit per liter; $\mathrm{mg} / \mathrm{dL}$ : Milligram per deciliter.

\subsection{Measurement of Sex Hormone}

The effects of the Biofield Energy Treated and untreated test formulations on sex hormone like testosterone in male rats are shown in the Figure 4. The level of testosterone was significantly increased by $22.02 \%$ in the Biofield Energy Treatment group per se at day -15 (G6) compared with the G2 group. Additionally, the level of testosterone was altered in the G3 and G4 groups compared with the G2 group. Ashwagandha (Withania somnifera) has been described in the traditional Indian Ayurvedic medicine as an aphrodisiac that can be used to treat male sexual dysfunction and infertility. From the scientific literature it was evident that ashwagandha root extract has increased in sperm concentration, ejaculate volume, and motile sperm count and an increased in the serum levels of testosterone [41]. Cinar et al. reported that the supplementation of magnesium $(\mathrm{Mg})$ had increased the both free and total testosterone levels [42]. Garcia et al. (2012) reported that zinc protect the male sexual organ and simultaneously increased the level of serum testosterone, which was reduced by smoked male rats which was due to antioxidant and stimulant effects [43]. Researcher had found an ameliorative potential of sodium selenite and zinc sulfate on intensive-swimming-induced testicular disorders, and significantly reduced the plasma level of testosterone in mature male rats [44]. The study results showed the supplementation with zinc chloride, sodium selenate, ashwagandha root extract, and magnesium gluconate as a formulated product did not increase to some extent, although each compounds have stimulatory effects on testosterone per se. This was happened might be due to the effects of interaction among them. 


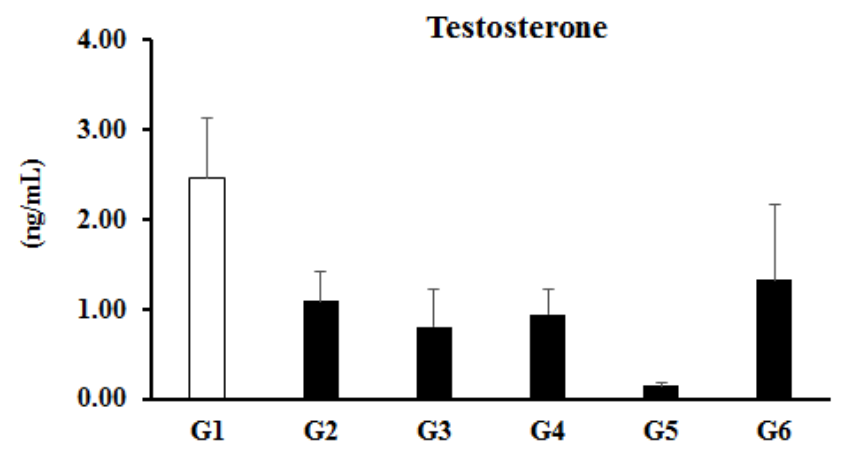

Figure 4. The effects of the Biofield Energy Treated and untreated test formulations on testosterone in male rats. All the values are represented as mean $\pm \operatorname{SEM}(n=6)$.

\section{Conclusions}

The current results indicated that, the ratio of the $\mathrm{CD}^{+} / \mathrm{CD}^{+}$was significantly increased by $51.98 \%$ in the Biofield Energy Treated test formulation (G3) compared with the disease control group (G2). Besides, the level of IgM was also significantly increased by $28.57 \%$ in the G3 group compared with the G2 group. The G3 group showed a significant decreased the level of lipid biomarkers such as TG and VLDL by $8.99 \%$ and $9.12 \%$, respectively compared with the G2 group. Moreover, the level of cardio-biomarker CK-MB was significantly reduced by $7.67 \%$ in the G3 group compared with the G2 group. The IgM was significantly increased by $28.57 \%$ in the G3 group compared with the G2 group. Therefore, it is assumed that The Trivedi Effect ${ }^{\circledR}$ Energy of Consciousness Healing Treatment to the test formulation shown a significant impact on immune, cardiac, and lipid biomarkers. The Trivedi Effect ${ }^{\circledR}$ - Energy of Consciousness Healing Treatment administered remotely by the eighteen Biofield Energy Healers enhanced the herbomineral test formulation's anti-inflammatory and immunomodulatory properties without any adverse effect to the animals throughout the exposure period. Overall, it can be concluded that the novel herbomineral formulation showed better immunomodulatory action compared with the untreated test formulation against many infectious diseases like Lupus, Addison Disease, Celiac Disease (glutensensitive enteropathy), Dermatomyositis, Graves' Disease, Hashimoto Thyroiditis, Multiple Sclerosis, Myasthenia Gravis, Pernicious Anemia, Aplastic Anemia, Reactive Arthritis, Rheumatoid Arthritis, Sjogren Syndrome, Systemic Lupus Erythematosus, Type 1 Diabetes, Alopecia Areata, Crohn's Disease, Fibromyalgia, Vitiligo, Psoriasis, Scleroderma, Chronic Fatigue Syndrome and Vasculitis, as well as inflammatory disorders such as Asthma, Ulcerative Colitis, Alzheimer's Disease, Atherosclerosis, Dermatitis, Diverticulitis, Hepatitis, Irritable Bowel Syndrome, Parkinson's Disease, etc. Further, The Trivedi Effect ${ }^{\circledR}$ Treated test formulation can also be used in the prevention of immune-mediated tissue damage in cases of organ transplants (for example heart transplants, kidney transplants and liver transplants), for autoimmune disorders, anti-aging, stress prevention and management, and for the improvement of overall health and quality of life.

\section{Abbreviations}

Na-CMC: Sodium carboxymethyl cellulose, SD: Sprague Dawley, TC: Total cholesterol, TG: Triglycerides, LDL: Low density lipoprotein, HDL: High density lipoprotein, VLDL: Very low density lipoprotein, ALP: Alkaline phosphatase, SGOT: Serum glutamic oxaloacetic transaminase, SGPT: Serum glutamate-pyruvate transaminase, TLC: Total leukocyte count, DLC: Differential leukocyte count, CK-MB: Creatine kinase myocardium band.

\section{Acknowledgements}

The authors are grateful to Dabur Research Foundation, Trivedi Science, Trivedi Global, Inc., Trivedi testimonials and Trivedi Master Wellness for their support throughout the work.

\section{References}

[1] Thomson GE (2007) The health benefits of traditional chinese plant medicines: Weighing the scientific evidence: A report for the rural industries research and development corporation, RIRDC, Barton, Australia.

[2] Rishton GM (2008) Natural products as a robust source of new drugs and drug leads: Past successes and present day issues. Am J Cardiol 101: 43D-49D.

[3] Mukhtar M, Arshad M, Ahmad M, Pomerantz R, Wigdahl B, Parveen Z (2008) Antiviral potentials of medicinal plants. Virus Res 131: 111-120.

[4] Wang JZ, Mao XJ, Ito H, Shimura K (1991) Immunomodulatory activity of polysaccharide from Acanthopanex obovatus roots. Planta Med 57: 335-336.

[5] Lukác N, Massányi P (2007) Effects of trace elements on the immune system. Epidemiol Mikrobiol Imunol 56: 3-9.

[6] Galland L (1988) Magnesium and immune function: An overview. Magnesium 7: 290-299.

[7] Wintergerst ES, Maggini S, Hornig DH (2007) Contribution of selected vitamins and trace elements to immune function. Ann Nutr Metab 51: 301 - 323.

[8] Ziauddin M, Phansalkar N, Patki P, Diwanay S, Patwardhan B (1996) Studies on the immunomodulatory effects of ashwagandha. J Ethnopharmacol 50: 69-76.

[9] Singh N, Bhalla M, de Jager P, Gilca M (2011) An overview on ashwagandha: A Rasayana (Rejuvenator) of Ayurveda. Afr J Tradit Complement Altern Med 8: 208-213.

[10] Mager J, Moore D, Bendl D, Wong B, Rachlin K, Yount G (2007) Evaluating biofield treatments in a cell culture model of oxidative stress. Explore (NY) 3: 386-390.

[11] Jain S, Hammerschlag R, Mills P, Cohen L, Krieger R, Vieten C, Lutgendorf S (2015) Clinical studies of biofield therapies: Summary, methodological challenges, and recommendations. Glob Adv Health Med 4: 58-66. 
[12] Rubik B (2002) The biofield hypothesis: Its biophysical basis and role in medicine. J Altern Complement Med 8: 703-717.

[13] Trivedi MK, Patil S, Shettigar H, Mondal SC, Jana S (2015) The potential impact of biofield treatment on human brain tumor cells: A time-lapse video microscopy. J Integr Oncol 4: 141.

[14] Trivedi MK, Patil S, Shettigar H, Gangwar M, Jana S (2015) In vitro evaluation of biofield treatment on cancer biomarkers involved in endometrial and prostate cancer cell lines. J Cancer Sci Ther 7: 253-257.

[15] Trivedi MK, Patil S, Shettigar H, Mondal SC, Jana S (2015) In vitro evaluation of biofield treatment on Enterobacter cloacae: Impact on antimicrobial susceptibility and biotype. J Bacteriol Parasitol 6: 241.

[16] Trivedi MK, Patil S, Shettigar H, Mondal SC, Jana S (2015) Evaluation of biofield modality on viral load of hepatitis B and C Viruses. J Antivir Antiretrovir 7: 083-088.

[17] Trivedi MK, Patil S, Shettigar H, Mondal SC, Jana S (2015) An impact of biofield treatment: Antimycobacterial susceptibility potential using BACTEC 460/MGIT-TB System. Mycobact Dis 5: 189.

[18] Trivedi MK, Branton A, Trivedi D, Nayak G, Mondal SC, Jana S (2015) Antimicrobial sensitivity, biochemical characteristics and biotyping of Staphylococcus saprophyticus: An impact of biofield energy treatment. J Women's Health Care 4: 271.

[19] Trivedi MK, Branton A, Trivedi D, Nayak G, Mondal SC, Jana S (2015) Evaluation of antibiogram, genotype and phylogenetic analysis of biofield treated Nocardia otitidis. Biol Syst Open Access 4: 143.

[20] Trivedi MK, Branton A, Trivedi D, Nayak G, Charan S, Jana S (2015) Phenotyping and 16S rDNA analysis after biofield treatment on Citrobacter braakii: A urinary pathogen. J Clin Med Genom 3: 129.

[21] Trivedi MK, Patil S, Shettigar H, Bairwa K, Jana S (2015) Spectroscopic characterization of chloramphenicol and tetracycline: An impact of biofield. Pharm Anal Acta 6: 395.

[22] Trivedi MK, Patil S, Shettigar H, Bairwa K, Jana S (2015) Spectroscopic characterization of biofield treated metronidazole and tinidazole. Med Chem 5: 340-344.

[23] Trivedi MK, Branton A, Trivedi D, Nayak G, Saikia G, Jana S (2016) Determination of isotopic abundance of ${ }^{2} \mathrm{H},{ }^{13} \mathrm{C},{ }^{18} \mathrm{O}$, and ${ }^{37} \mathrm{Cl}$ in biofield energy treated dichlorophenol isomers. Science Journal of Analytical Chemistry 4: 1-6.

[24] Trivedi MK, Branton A, Trivedi D, Shettigar H, Bairwa K, Jana S (2015) Fourier transform infrared and ultravioletvisible spectroscopic characterization of biofield treated salicylic acid and sparfloxacin. Nat Prod Chem Res 3: 186.

[25] Trivedi MK, Branton A, Trivedi D, Nayak G, Gangwar M, Jana S (2016) Molecular analysis of biofield treated eggplant and watermelon crops. Adv Crop Sci Tech 4: 208.

[26] Trivedi MK, Branton A, Trivedi D, Nayak G, Mondal SC, Jana S (2015) Morphological characterization, quality, yield and DNA fingerprinting of biofield energy treated alphonso mango (Mangifera indica L.). Journal of Food and Nutrition Sciences 3: 245-250.

[27] Trivedi MK, Branton A, Trivedi D, Nayak G, Mondal SC,
Jana S (2015) Evaluation of plant growth, yield and yield attributes of biofield energy treated mustard (Brassica juncea) and chick pea (Cicer arietinum) seeds. Agriculture, Forestry and Fisheries 4: 291-295.

[28] Trivedi MK, Branton A, Trivedi D, Nayak G, Mondal SC, Jana S (2015) Evaluation of plant growth regulator, immunity and DNA fingerprinting of biofield energy treated mustard seeds (Brassica juncea). Agriculture, Forestry and Fisheries 4: 269-274.

[29] Trivedi MK, Tallapragada RM, Branton A, Trivedi D, Nayak G, Jana S (2015) Characterization of physical and structural properties of aluminum carbide powder: Impact of biofield treatment. J Aeronaut Aerospace Eng 4: 142.

[30] Trivedi MK, Nayak G, Patil S, Tallapragada RM, Latiyal O, Jana S (2015) Impact of biofield treatment on atomic and structural characteristics of barium titanate powder. Ind Eng Manage 4: 166.

[31] Trivedi MK, Patil S, Nayak G, Jana S, Latiyal O (2015) Influence of biofield treatment on physical, structural and spectral properties of boron nitride. J Material Sci Eng 4: 181.

[32] Trivedi MK, Nayak G, Patil S, Tallapragada RM, Latiyal O, Jana S (2015) Characterization of physical and structural properties of brass powder after biofield treatment. J Powder Metall Min 4: 134.

[33] Ladics GS (2007) Primary immune response to sheep red blood cells (sRBC) as the conventional T-cell dependent antibody response (TDAR) test. J Immunotoxicol 4: 149-152.

[34] Uppal SS, Verma S, Dhot PS (2003) Normal values of CD4 and CD8 lymphocyte subsets in healthy Indian adults and the effects of sex, age, ethnicity, and smoking. Cytometry B Clin Cytom 52: 32-36.

[35] Mikolai J, Erlandsen A, Murison A, Brown KA, Gregory WL, Raman-Caplan P, Zwickey HL (2008) In vivo effects of ashwagandha (Withania somnifera) extract on the activation of lymphocytes. J Altern Complement Med 15: 423-430.

[36] Yamada K, Hung P, Park TK, Park PJ, Limb BO (2011) A comparison of the immunostimulatory effects of the medicinal herbs echinacea, ashwagandha and brahmi. J Ethnopharmacol 137: 231-235.

[37] Solomons NW (1998) Mild human zinc deficiency produces an imbalance between cell-mediated and humoral immunity. Nutr Rev 56: 27-28.

[38] Jung Y, Rothenberg ME (2014) Roles and regulation of gastrointestinal eosinophils in immunity and disease. J Immunol 193: 999-1005.

[39] Galioto AM, Hess JA, Nolan TJ, Schad GA, Lee JJ, Abraham D (2006) Role of eosinophils and neutrophils in innate and adaptive protective immunity to larval Strongyloides stercoralis in mice. Infect Immun 74: 5730-5738.

[40] Sultana N, Shimmi AC, Hossain MT, Akhtar J (2012) Effects of ashwagandha (Withania somnifera) root extract on some serum liver marker enzymes (AST, ALT) in gentamicin intoxicated rats. J Bangladesh Soc Physiol 7: 1-7.

[41] Ambiye VR, Langade D, Dongre S, Aptikar P, Kulkarni M, Dongre A (2013) Clinical evaluation of the spermatogenic activity of the root extract of ashwagandha (Withania somnifera) in oligospermic males: A pilot study. Evid Based Complement Alternat Med 2013: 571420. 
[42] Cinar V, Polat Y, Baltaci AK, Mogulkoc R (2011) Effects of magnesium supplementation on testosterone levels of athletes and sedentary subjects at rest and after exhaustion. Biol Trace Elem Res 140: 18-23.

[43] Garcia PC, Piffer RC, Gerardin DC, Sankako MK, Alves de Lima RO, Pereira OC (2012) Could zinc prevent reproductive alterations caused by cigarette smoke in male rats? Reprod Fertil Dev 24: 559-567.
[44] Jana K, Samanta PK, Manna I, Ghosh P, Singh N, Khetan RP, Ray BR (2008) Protective effect of sodium selenite and zinc sulfate on intensive swimming-induced testicular gamatogenic and steroidogenic disorders in mature male rats. Appl Physiol Nutr Metab 33: 903-914. 